\title{
Archaeological monuments of the Warmian-Masurian voivodeship - spatial analysis using GIS tools
}

\author{
Krzysztof Rząsa $^{1, *}$, and Mateusz Ciski ${ }^{1}$ \\ ${ }^{1}$ Faculty of Geodesy, Geospatial and Civil Engineering, Institute of Geography and Land Management, University of Warmia \\ and Mazury in Olsztyn, Prawochenskiego Street 15, 10-720 Olsztyn, Poland
}

\begin{abstract}
Archaeological monuments are one of the forms of monument protection in Poland. It includes various objects, among which one can distinguish: field remnants of prehistoric and historical settlements, graveyards, burial mounds and single graves, as well as relics of industrial, religious and artistic activity. All these objects are of great importance in spatial planning, and its location possess a big impact on the possibilities of land development. According to The National Heritage Board of Poland database for September 2018, there are 7672 archaeological monuments registered in the polish register of objects of cultural heritage. The number of archaeological objects entered in the register in individual voivodeships is varied. The majority of monuments is located in the Lower Silesian voivodeship, the least in Łódź voivodeship. In this article, archaeological monuments in the Warmian-Masurian voivodeship were analysed, in which there are 286 of such objects. Identification with regard to function was carried out, and a detailed location was specified. With the use of GIS tools, a series of maps was created, which after analysing became the basis for formulating final conclusions. Some of it can be used in the preparation of planning documents at the voivodeship and municipal level.
\end{abstract}

\section{Introduction}

The Act on the Protection of Monuments and the Care of Historical Monuments [1] introduces in Article 7 the following forms of protection of monuments in Poland: an entry in the register of objects of cultural heritage (pol. rejestr zabytków), an entry on the List of Heritage Treasures (pol. Lista Skarbów Dziedzictwa), recognition of an object or area as a Historic Monument (pol. pomnik historii), establishing a Cultural Park (pol. park kulturowy) and protection regulations in spatial planning documents. Archaeological monuments are among the objects entered in the register of objects of cultural heritage. According to Article 3 of the Act, an archaeological monument is a non-movable monument, a surface, underground or underwater remnant of human existence and activity, composed of cultural layering and the products or traces found therein, or a movable monument that is this product. Archaeological monuments are in particular: field remnants of prehistoric and historical settlements, graveyards, burial mounds and single graves, as well as relics of industrial, religious and artistic activity. Archaeological monuments are inscribed in Book $\mathrm{C}$ of the register of objects of cultural heritage.

Such objects are an element of cultural heritage and are subject to the principles of protection characteristic of this type of objects. Such activities can be observed all over the world [2-4]. The cultural heritage is the wealth, which connects people with the past, gives a

\footnotetext{
* Corresponding author: krzysztof.rzasa@uwm.edu.pl
}

solid foundation for the present and gives the way to the future [5].

The location of archaeological monuments, as well as other non-movable monuments and Cultural Parks or Historic Monuments, has a large impact on the development of land, especially in their immediate vicinity and must be taken into account in spatial planning [6-8]. Archaeological sites, as highly complex parts of the cultural heritage, require special care in all parts of planning, research, conservation and presentation [9].

This article is a detailed analysis of archaeological monuments located in the Warmian-Masurian Voivodeship. Archaeological monuments were identified, their functions were analysed, the exact location was determined, to finally make detailed analyses on the maps generated using the GIS tools. All this allowed to formulate the conclusions presented in the last part of the article.

\section{Materials and methods}

In the first stage of the study, an analysis of existing legal provisions and literature thematically related to the analysed topic was conducted. In this way, the main principles of the functioning of the monument protection system in Poland were determined, with particular reference to archaeological monuments.

In the next stage, the focus was put on a detailed inventory of archaeological monuments in Poland, in particular in the Warmian-Masurian Voivodeship. 
Quantitative and generic data was obtained from the National Heritage Board of Poland [10]. In Poland, 7 672 archaeological monuments are entered into the Book of $\mathrm{C}$ of the voivodeship register of objects of cultural heritage. The number of archaeological monuments entered in the register in individual voivodeships is varied. Majority of such monuments is located in the Lower Silesian voivodeship (19.19\%), Opole voivodeship (15.46\%), Greater Poland voivodeship (8.68\%), Pomeranian voivodeship $(7.38 \%)$ and Lubusz voivodeship $(7.09 \%)$; the minority in the Łódź voivodeship (1.86\%), Lublin voivodeship (2.20\%) and Kuyavian-Pomeranian voivodeship $(2.49 \%)$. In the analysed Warmian-Masurian voivodeship there are $3.73 \%$ of this type of objects. The detailed number of archaeological monuments in individual voivodeships is shown in Fig.1.

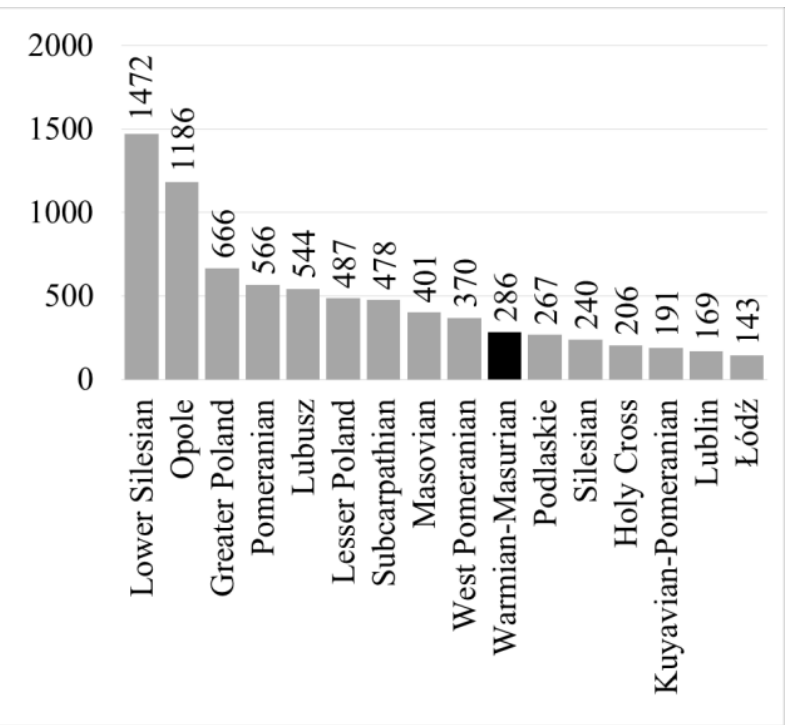

Fig. 1. The number of archaeological monuments, divided into polish voivodeships.

Regional disparities are even more visible when the number of monuments is related to the area of voivodeships. The highest ratio occurs for the Opole voivodeship (126 monuments per $1000 \mathrm{~km} 2$ area) and Lower Silesia voivodeship (74), and the lowest for the Lublin voivodeship (7) and Łódź voivodeship (8), with the national average of 25 monuments per $1000 \mathrm{~km}^{2}$ area. The Warmian-Masurian voivodeship is below the national average $\left(11\right.$ monuments per $\left.1000 \mathrm{~km}^{2}\right)$. Detailed data is provided in Fig. 2.

For the needs of a detailed inventory, based on data from the Report prepared by The National Heritage Board of Poland [10], archaeological monuments were divided according to its function. The following functional groups have been used:

- defensive (including strongholds, fortifications, etc.),

- ritual (including: churches, temples, chapels, monastic complexes, eremitical stone circles, places of worship, sacrificial sites, etc.),

- settlement / residential (including: manors, cities, palaces, architectural relics, settlements, villages, camps, caves, rock shelters, settlement traces, etc.),
- sepulchral-graves (including: burial mounds and megalithic graves),

- sepulchral-graveyards (including: burial grounds, megalithic burial grounds),

- industrial (including: infrastructure, places of raw material exploitation, production sites),

- various (including settlement complexes, mounds, shafts, multi-phase stations with different functions).

Detailed data on the number of individual types of archaeological monuments in the Warmian-Masurian Voivodeship is shown in Fig. 3.

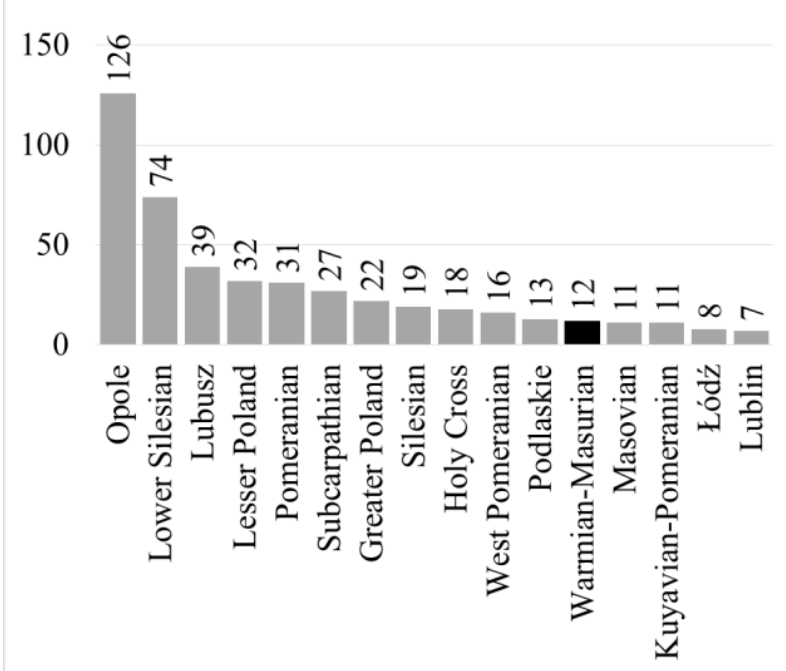

Fig. 2. The number of archaeological monuments per $1000 \mathrm{~km}^{2}$, divided into Polish voivodeships.

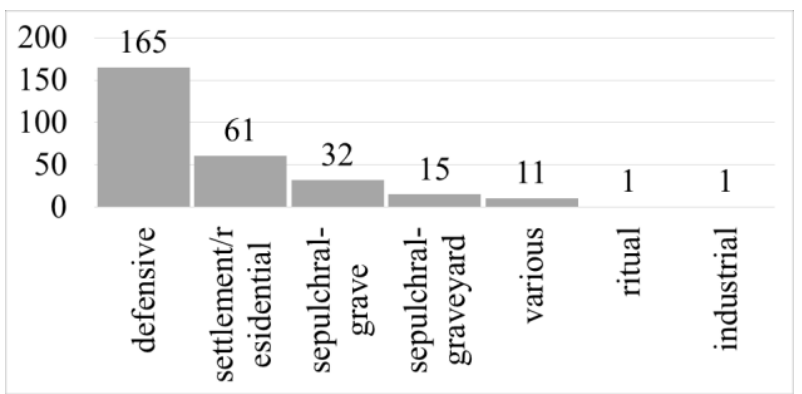

Fig. 3. Archaeological monuments in the Warmian-Masurian voivodeship, division by function.

Apart from the functional division, archaeological monuments can be divided according to the estimated time of their creation [10], for example: prehistory, stone age, bronze age, iron age, early middle ages, middle ages, modern era, etc. Detailed data on the number of archaeological monuments in individual chronological groups in the Warmian-Masurian Voivodeship can be found in Fig. 4.

National Heritage Board of Poland through geoportal (mapy.zabytek.gov.pl/nid) provides online information about objects entered in the register of objects of cultural heritage, free of charge. However, in order to carry out studies on the spatial distribution of the analysed elements, precise point data had to be obtained. Such data cannot be obtained automatically 
from the National Heritage Board of Poland geoportal, so it was necessary to have it manually collected.

Data on objects entered in the register of objects of cultural heritage as archaeological monuments were obtained from the Otwarte Dane portal (dane.gov.pl). In order to create a point layer necessary for analysis, the tabular data had to be associated with geographical coordinates. The original assumption was to analyse the entire country, but due to the amount of information needed (geographical coordinates of 7672 points), as well as the universality of the methodology used, the area of the Warmian-Masurian voivodeship was analysed.

After supplementing tabular data with information on geographical coordinates, the database was completed with information on functional categories, previously defined. Information on the time of the objects' creation was also added. The prepared table was converted into a point cloud using the "Make XY Event Layer" of the ArcMap component of the ArcGIS software. After collecting quantitative and generic data, the next step was to analyse using GIS tools.

In order to determine the spatial distribution of the analysed objects, the Kernel Density function was used. Abandoning the limitations resulting from the territorial division allowed for a more detailed analysis [11-15], and the nature and age of archaeological monuments is exceptionally unrelated to the current administrative boundaries [16].

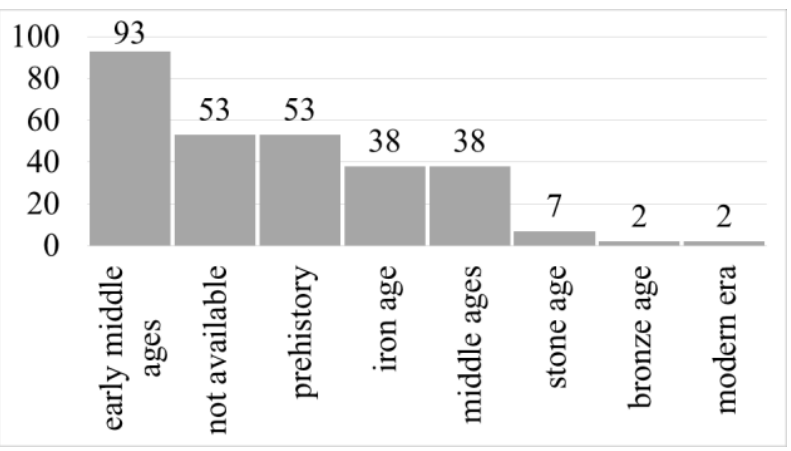

Fig. 4. Archaeological monuments in the Warmian-Masurian voivodeship, division by time of creation.

\section{Results and discussion}

The location of objects entered in the register of objects of cultural heritage as archaeological monuments, located in the Warmian-Masurian voivodeship, is presented in the form of a cartodiagram on Fig. 5.

The first stage of the study of saturation of archaeological monuments was to create a density map without division into functional or chronological groups, resulting in Fig. 6.

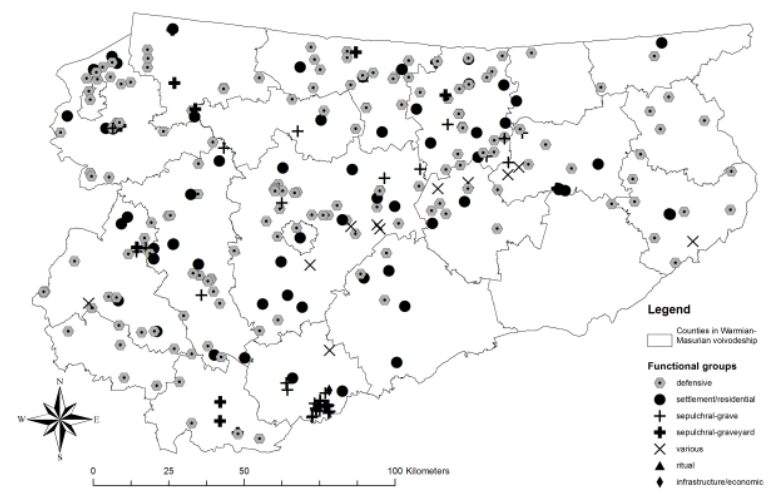

Fig. 5. Archaeological monuments, located in the WarmianMasurian voivodeship.

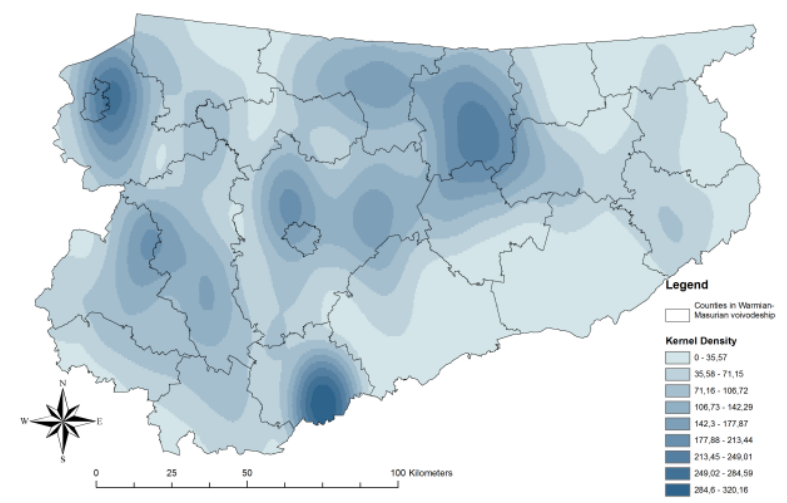

Fig. 6. Overall density of archaeological monuments in the Warmian-Masurian voivodeship.

The Warmian-Masurian voivodeship is characterized by a small number of archaeological monuments, however, they are fairly evenly distributed in the area of the voivodeship. The exception is the southeast of the voivodeship - there is no archaeological monument in the Pisz county.

The database, based on the occurrence of monuments in the area of the Warmian-Masurian Voivodeship, was divided into five functional groups. Four most numerous groups of objects were determinated: defensive, settlement/residential, sepulchral-graves and sepulchralgraveyards. Due to the small number of objects in groups: ritual and industrial (one object each), these were included in the group "various". The following figures successively shows the saturation of archaeological monuments of the functional groups: defensive (Fig. 7), settlement/residential (Fig. 8), sepulchral-graves (Fig. 9), sepulchral-graveyards (Fig. 10) and various (Fig. 11).

Because 115 out of 165 objects from the "defensive" function group are simultaneously in the chronological group "early middle ages" or "middle ages", the spatial distribution shown in Fig. 7 is not surprising - a large accumulation of objects near historic cities and fortresses can be seen (Giżycko, Kętrzyn, Olsztyn, Elbląg).

Due to the chronological diversity of objects from the "settlement/residential" function group, and lack of significant dominance of a specific historical period ( 7 objects were created in the stone age, 1 in the bronze age, 13 in the iron age, 1 in the early middle ages, 5 in the middle ages, 7 in prehistory and 1 in modern era), 
and also due to the very general and basic nature of the group, Fig. 8 shows a similar spatial distribution as the general approach, excluding the southern part of the voivodeship.

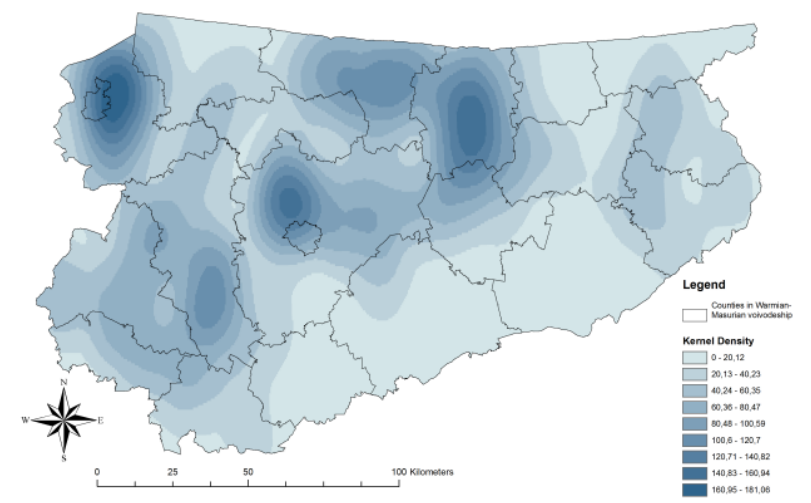

Fig. 7. Archaeological monuments in the "defensive" functional group, located in the Warmian-Masurian voivodeship.

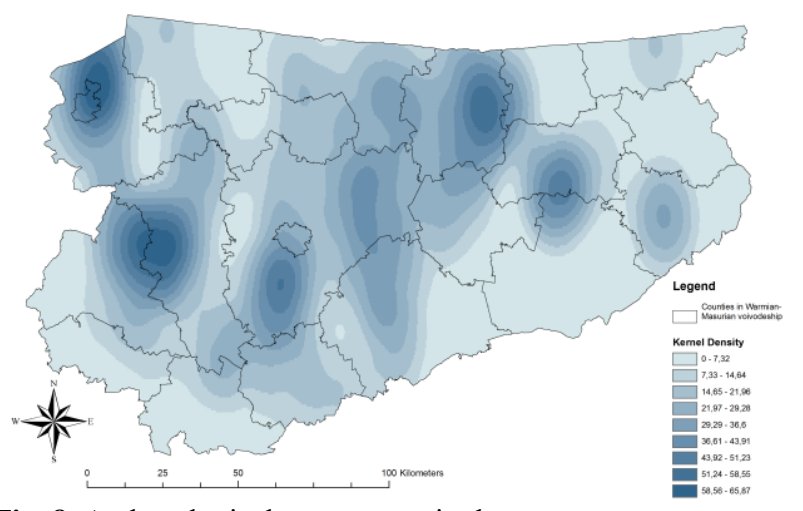

Fig. 8. Archaeological monuments in the "settlement/residential" functional group, located in the Warmian-Masurian voivodeship.

Fig. 9 shows the spatial distribution of the "sepulchral-graves" functional group. The Nidzica county is definitely dominating the distribution. 31 of 32 objects from this group were created in prehistoric times.

The spatial distribution of the "sepulchralgraveyards" function group is shown in Fig. 10. As in the case of Fig. 9, the largest density of objects from this group is located in the south of the voivodeship, in the Nidzica and Działdowo counties.

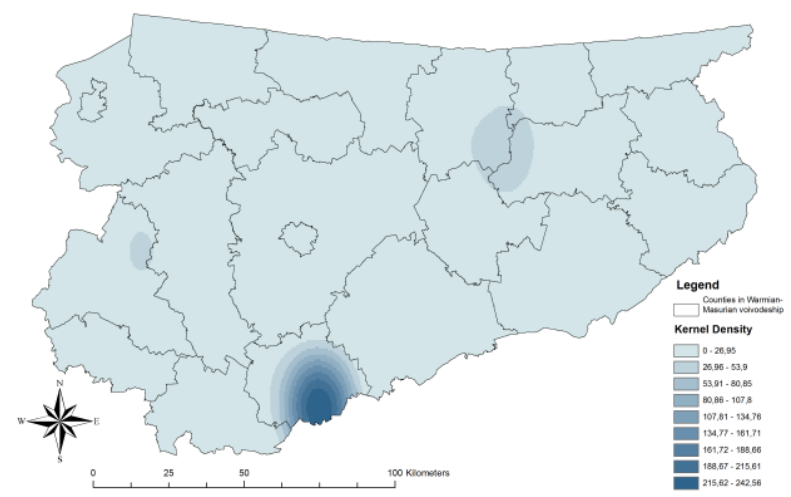

Fig. 9. Archaeological monuments in the "sepulchral-graves" functional group, located in the Warmian-Masurian voivodeship.

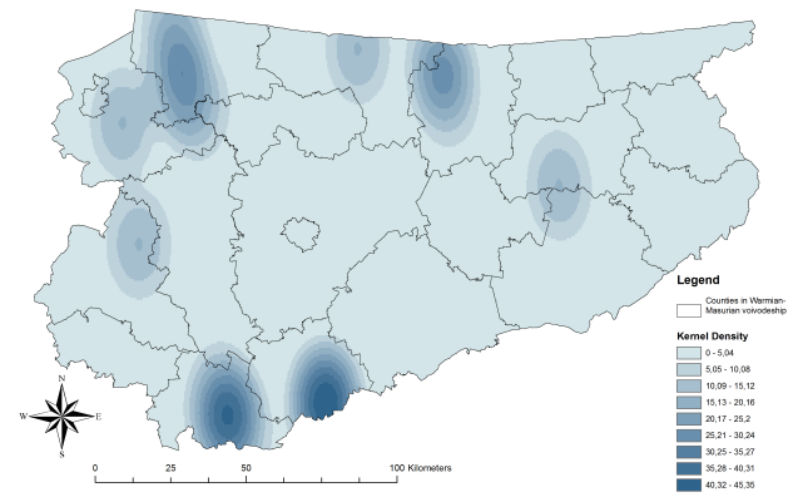

Fig. 10. Archaeological monuments in the "sepulchralgraveyards" functional group, located in the WarmianMasurian voivodeship.

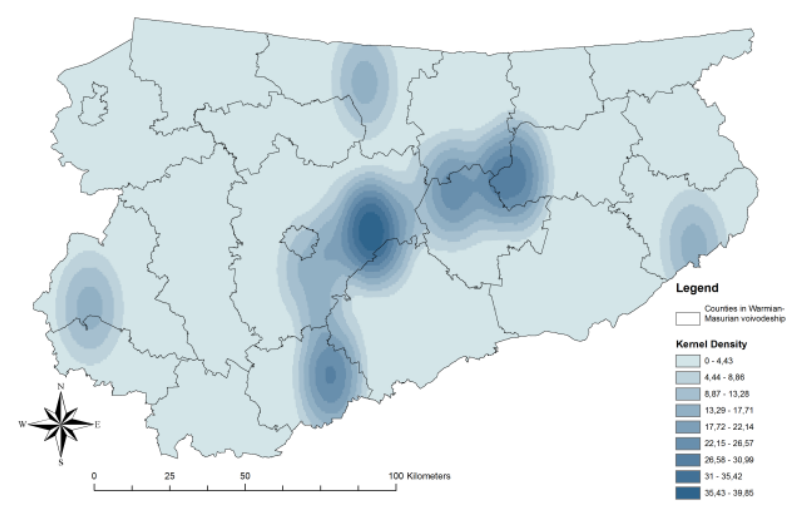

Fig. 11. Archaeological monuments in the "various" functional group, located in the Warmian-Masurian voivodeship.

Fig. 11 shows the spatial distribution of the "various" functional group. Objects from this group can be found primarily in the central part of the voivodeship.

In the final part, the periods of creation of the monuments were analysed, along with the location. In Fig. 12, using the cartodiagram, the chronological division of archaeological monuments in the area of Warmian-Masurian voivodeship is presented.

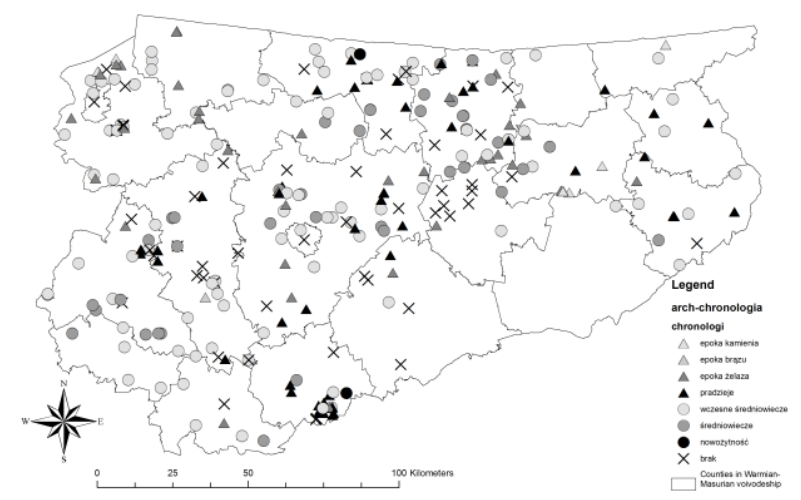

Fig. 12. Chronological division of archaeological monuments in the area of Warmian-Masurian voivodeship.

Due to the small number of objects in selected groups (7 objects from the stone age, 1 from the bronze age, 2 from modern era), Fig. 13, 14, and 15 used a generalized division into three groups: the oldest objects (from chronological groups: stone age, bronze age, iron age 
and prehistory), early medieval (from "early middle ages" chronological group) and the youngest objects (from chronological groups: middle ages and modern era). The analysis covered 233 objects, 53 archaeological monuments whose time of creation is impossible to determine, were omitted.

The largest density of the oldest objects can be seen in the southern part of the map, the area around today's Nidzica county. A spatial correlation can be seen with Fig. 9 and Fig. 10, depicting sepulchral objects.

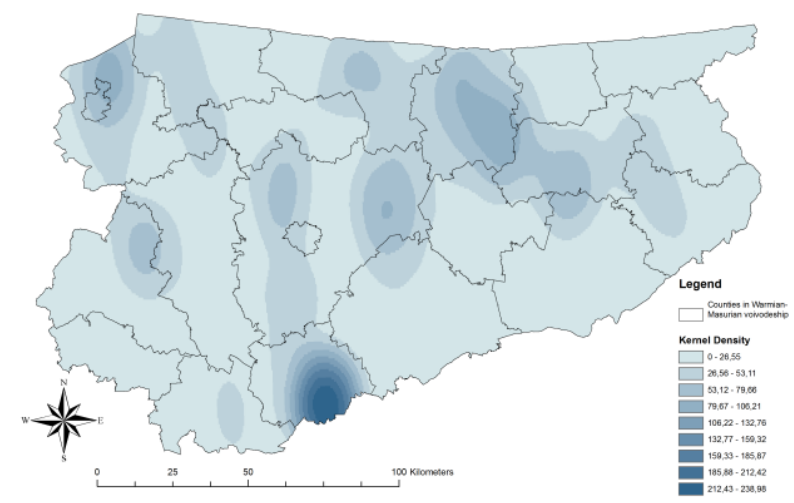

Fig. 13. Archaeological monuments in the "oldest objects" chronological group, located in the Warmian-Masurian voivodeship

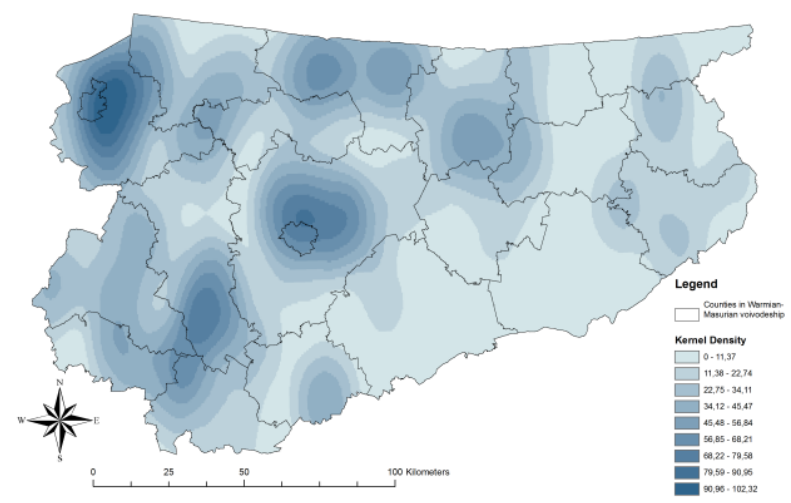

Fig. 14. Archaeological monuments in the "early medieval" chronological group, located in the Warmian-Masurian voivodeship

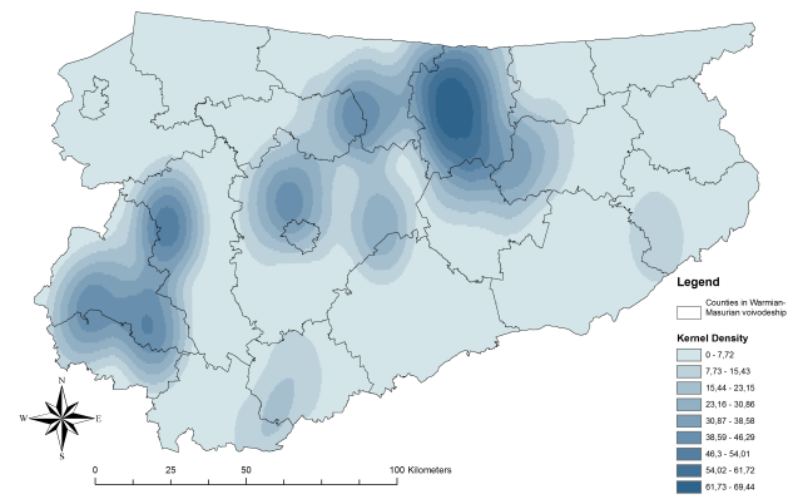

Fig. 15. Archaeological monuments in the "youngest objects" chronological group, located in the Warmian-Masurian voivodeship
Fig. 14 shows a spatial correlation with Fig. 6, showing the spatial distribution of all archaeological monuments in the Warmian-Masurian Voivodeship. This may be due to the fact that almost $42 \%$ of the analysed objects are from early middle ages.

Fig. 15 shows a spatial correlation with Fig. 7, which confirms the conclusions contained in the analysis under this figure.

\section{Conclusions}

1. Archaeological monuments, due to the age of its creation, indicate a complete lack of connection with current administrative borders. By abandoning the artificial boundaries and analysing the exact position of the examined objects, a more accurate view of the spatial distribution was obtained.

2. The conducted research allowed to conclude, that due to the need to limit the analysis in a unified and welldefined spatial framework, the boundaries of historical lands, not today's administrative boundaries, should be rather used. They should be determined on the basis of separate researches or analyses of historical maps.

3. The analyses made it possible to verify the spatial distribution of archaeological monuments in the Warmian-Masurian voivodeship, divided into various functional groups. Non-uniformity of their spatial distribution in the analysed area has been presented.

4. The analyses presented can be carried out both locally and regionally, for the whole country. They are universal in terms of area - can be made for any administratively, functionally or spatially separated area.

5. When creating the Municipality Development Strategy and Study of the Conditions and Directions of the Spatial Management of Municipality, local self-government must take into account the cultural and historical factors of the municipality. The presented analyses are a useful tool supporting the process of creating these documents. Similarly, it can be used in special cases when developing the local spatial management plans.

6. Local self-governments at the voivodeship level, in order to locate areas of exceptional historical value in a simple and quick way, may use similar analyses when creating and updating the Voivodeship Development Strategy and Voivodeship Spatial Management Plan.

\section{References}

1. The Act on the Protection of Monuments and the Care of Historical Monuments. Parliament. Journal of Laws from 2014, No 1446 as amended (2003)

2. P.M. Protopsaltis, Book Review: Cultural Heritage in International Investment Law and Arbitration, by Valentina Vadi. (Cambridge: Cambridge University Press). 35 Journal of International Arbitration, Kluwer Law International BV, The Netherlands. Issue 2/2018, pp. 267-271 (2014) 
3. E. Lagrange, S. Oeter, R. Uerpmann-Wittzack, eds. Cultural Heritage and International Law: Objects, Means and Ends of International Protection. Springer International Publishing, Basel. (2018) DOI:10.1007/978-3-319-78789-3

4. X. JIAO, J. WANG, Context Protection and Inheritance in the Process of Urbanization. 2nd International Conference on Education, Management and Applied Social Science (EMASS), pp. 170-174 (2018)

DOI:10.12783/dtssehs/emass2018/20409

5. L.B. Kakashvili, Archaeological museumreservations as a cultural investment. International scientific and practical conference world science ROST (Dubai). 2, no 12 (28), pp. 49-51 (2017)

6. K. Rzasa, M. Ogryzek, M. Kulawiak, Cultural Heritage in Spatial Planning, Baltic Geodetic Congress (BGC Geomatics), Gdańsk, pp. 85-89, 2016, DOI:10.1109/BGC.Geomatics.2016 (2016)

7. K. Rząsa. Kulturowe aspekty planowania przestrzennego na obszarach wiejskich. Kształtowanie przestrzeni wiejskiej. UWM w Olsztynie. pp.139-154. (2017)

8. M. Ciski, K. Rząsa. Cultural Parks in The Spatial Planning System in Poland. Baltic Geodetic Congress (BGC Geomatics), Olsztyn. pp. 145-149 (2018) DOI:10.1109/BGC-Geomatics.2018.00033

9. A. Momčilovic-Petronijević, P. Petronijević, M. Mitković. Degradation of archeological sites - case study Caričin Grad. University of Niš, Serbia. Facta Universitatis Series: Architecture and Civil Engineering 16, No 2. (2018) DOI:10.2298/FUACE171201006M

10. Raport o stanie zachowania zabytków nieruchomych w Polsce, Narodowy Instytut Dziedzictwa, Warszawa (2017) (in Polish)

11. Z. Qin, W. Li, and X. Xiong, Estimating wind speed probability distribution using kernel density method, Electric Power Systems Research, 81, no. 12, pp. 2139-2146 (2011)

12. E. García-Portugués, R. M. Crujeiras, and W. González-Manteiga, "Kernel density estimation for directional-linear data," Journal of Multivariate Analysis, vol. 121, pp. 152-175. (2013)

13. J. Kim and C. Kim, Reducing the mean squared error in kernel density estimation, Journal of the Korean Statistical Society, 42, no. 3, pp. 387-397 (2013)

14. M. S. Gerber, Predicting crime using Twitter and kernel density estimation, Decision Support Systems, 61, pp. 115-125 (2014)

15. E. Saule, D. Panchananam, A. Hohl, W. Tang, and E. Delmelle, Parallel Space-Time Kernel Density Estimation, International Conference on Parallel Processing, pp. 483-492 (2017)

16. A. Fiedukowicz, A. Głażewski, A. Kołodziej, K. Koszewski, P. Kowalski, R. Olszewski, and L. Włochyński. Map Portal as a Tool to Share
Information on Cultural Heritage Illustrated by the National Heritage Board Geoportal. Advances in Digital Cultural Heritage International Workshop Funchal, Madeira, Portugal, June 28. Springer International Publishing AG, Switzerland. pp.48-64 (2017) DOI:10.1007/978-3-319-75789-6 